\title{
FALL FOOD OF THE EASTERN SCREECH-OWL IN MANITOBA
}

KURT M. MAZUR, 15 Attache Place, Winnipeg, Manitoba. R2V 3L3

The Eastern Screech-owl is one of the most widespread owls in North America. ${ }^{4}$ It ranges from the Gulf of Mexico north to southern Manitoba, and from Montana to the east coast of the United States. ${ }^{14}$ This small (20-24 cm) highly nocturnal owl has a diet that is quite varied over its range and throughout the season. ${ }^{1,4,5,11,12,15,16,18 \text { Several }}$ studies of the Eastern Screech-owl's diet have been published, but none from the northern edge of its range. $5,15,16,18$ Reports of Eastern Screech-owls in Manitoba occur as far north as Riding Mountain National Park. ${ }^{1}$

This study was done near Winnipeg in autumn, a time when numbers and types of prey available are changing. $7,13,16$ The study area was in La Barriere Park along the La Salle River, just south of Winnipeg. The vegetative cover consisted primarily of Manitoba Maple (Acer negundo), Green Ash (Fraxinus pennsylvanicus), Bur Oak (Quercus macrocarpa) and Red Osier Dogwood (Cornus stolonifera). The land outside the wooded area is agricultural prairie, creating an ecotone. All prey remains were collected from and around Wood Duck nest boxes from La Barriere Park where a resident Eastern Screech-owl was seen. As Eastern Screech-owls are cavity nesters, Wood Duck nest boxes are a readily accessible nest and roost site. Through examination of the prey remains, an owl's diet can be accurately quantified. ${ }^{6,8}$

Starting 13 October 1990,40 nest boxes were checked for prey remains. Five of these contained pellets and/or bones and feathers, presumably the prey of the resident screech-owl. These five boxes, and the surrounding areas, were checked once a week from 13 October to 4 November 1990.

Prey were identified to species when possible. Mean individual prey weight was estimated by taking the average weight of five individuals of each species from the same time of year, based on data from Manitoba specimen collections. ${ }^{9}$ From these individual prey weights a percent total weight was calculated for the prey species (Table 1).

A total of 26 individual prey items were identified from 17 pellets and prey remains. Thirteen of these were mammals: Meadow voles (Microtus pennsylvanicus), Deer Mice (Peromyscus maniculatus), Redbacked Voles (Clethrionomys gapperi) and unidentified small rodents (Table 1).

Variation in the number of species and weights of birds found in the prey remains was much greater than that in mammals (Table 1). The 
Table 1: Prey Remains of Eastern Screech-owl Pellets.

Prey items \# Individuals \% Total Prey

Mean Weight (g)

$\%$ Biomass

Mammals

Meadow Vole

Deer Mouse

Red-backed Vole

Unidentified small

mammals

Total

$\begin{array}{cr}3 & 11.5 \\ 2 & 7.7 \\ 3 & 11.5 \\ \frac{5}{13} & \frac{19.2}{49.9}\end{array}$

74.7

10.7

32.0

4.6

54.6

7.8

\section{Birds}

Northern Flicker

White-breasted

Nuthatch

Purple Finch

Bohemian Waxwing

Rose-breasted

Grosbeak

American Robin

Unidentified

passerines

Total

$\begin{array}{cc}2 & 7.7 \\ 2 & 7.7 \\ 2 & 7.7 \\ 1 & 3.8 \\ 1 & 3.8 \\ 1 & 3.8 \\ \frac{4}{13} & \frac{15.4}{49.9}\end{array}$

252.0

36.1

45.4

6.5

51.0

60.2

8.6

43.6

85.6

12.3

$\overline{77.0}$

Northern Flicker only represented $7.1 \%$ of the total prey but, with an estimated mean weight of 126.0 grams, it accounted for $31.6 \%$ of the total biomass. White-breasted Nuthatches and Purple Finches each constituted $7.7 \%$ of the total prey and $6.5 \%$ and $7.3 \%$ of the weights, respectively. The Bohemian Waxwing, Rosebreasted Grosbeak and American Robin each accounted for $3.8 \%$ of the total prey and $8.6 \%, 6.2 \%$ and $12.3 \%$ of the total biomass, respectively.

The Eastern Screech-owl has a highly variable diet, perhaps due to its opportunistic nature, taking whatever prey is available. $2,4,5,10,16,18$ The highly diverse diet of the Eastern Screech-owl has been documented in more southerly reaches of its range. Small mammals (shrews, flying squirrels, chipmunks and bats), birds as large as Ruffed Grouse, amphibians, reptiles, invertebrates and, oddly enough, fish are all included in the diet of Eastern Screechowls. ${ }^{2,3,4,15,17}$ There are even reports of cannibalism occurring in this species. ${ }^{4}$ At least nine species of prey in this small sample demonstrate the highly variable diet as well as the opportunistic nature of the Eastern Screech-owl.

\section{Acknowledgements}

I would like to thank Spencer Sealy for the use of his avian collection and for help in identifying prey remains; W.O. Pruitt for access to his mammalian collection; Glen McMaster for field assistance; and Jim Duncan for a critical review of this paper.

1. ADAM, C.I.G. 1989. Eastern Screech-owl in Saskatchewan and adjacent areas. Blue Jay 47:165-188.

2. ALLEN, A.A. 1924. A contribution to the life history and economic status of the Screech Owl (Otus asio). Auk 41:1-16.

3. BARCLAY, M.R., C.E. THOMSON and F.J.S. PHELAN. 1982. Screech 
Owl, Otus asio, attempting to capture Little Brown Bats, Myotis lucifugus, at a colony. Can. Field Nat. 96:205-206.

4. BENT, A.C. 1938. Life histories of North American birds of prey. Vol. 2. Dover, New York. 482 pp.

5. BROWN, B.A., J.O. WHITAKER, T.W. FRENCH and C. MASER. 1986. Note on the food habits of the screech owl and the Burrowing Owl of southeastern Oregon. Great Basin Nat. 46:421-426.

6. DUKE, G.E., O.A. EVANSON and A. JEGERS. 1976. Meal to pellet intervals in 14 species of captive raptors. Comp. Biochem. Physiol. 53A:1-6.

7. EARHART, P.L. and N.K. JOHNSON. 1970. Size dimorphism and food habits of North American owls. Condor 72:251-264.

8. ERRINGTON, P.L. 1930. The pellet analysis method of raptor food habit study. Condor 32:292-296.

9. FAIRLY, J.S. and C.M. SMAL. 1988. Correction factors in the analysis of the pellets of the Barn Owl Tyto alba in Ireland. Proc. Royal Irish Academy 88B(8):119-133.

10. GEHLBACH, F.R. 1980. Population and environmental features that promote adaptation to urban ecosystems: the case of the Eastern Screech-owls (Otus asio) in Texas. pp. 1776-1830 in Acta XIX Cong. Intern. Ornith. Natl. Mus. Natur. Sci., Canada (1988).

11. GODFREY, W.E. 1986. The birds of Canada. Nat. Mus. Canada. Ottawa, Canada. 595 pp.

12. JOHNSGARD, P.A. 1988. North American owls. Smith. Inst., Washington.

13. JOHNSON, N.K. 1963. The supposed migratory status of the Flammulated Owl. Wilson Bull. 75:174-178.

14. ROBBINS, C.S., BESTEL BRUUN and H.S. ZIM. 1983. A guide to field identification. Birds of North America. Golden Press, New York. 360 pp.

15. ROSS, A. 1969. Ecological aspects of the food habits of insectivorous screech-owls. Proc. Western Foundation Vert. Zool. 1:301-344.

16. SMITH, D.G. and C.R. WILSON. 1971. Notes on the winter food of screech owls in central Utah. Great Basin Nat. 31:83-84.

17. TREAT, W.E. 1889. A fishing Screech Owl. Auk 6:189-190.

18. VANCAMP, L.F. and C.J. HENNY. 1975. The screech owl: its life history and population ecology in northern Ohio. N. Am. Fauna 71:65 pp.

Flowers stir our sense of beauty and lend a special charm to botanizing, whether in our gardens caring for roses and sweet peas or rambling in nature's paradise searching for rarer blooms. Flowering plants evolved along with our mammal ancestors; we grew up together during the last few hundred million years, and the roots of the attraction we feel for fragrant blossoms and bouquets lie deep within us. Stan Rowe, 1990. Home Place: Essays on Ecology. NeWest, Edmonton. 